\title{
位相差顕微鏡 $(\mathrm{PCM})$ 観察による穿刺液の細胞学的研究
}

\author{
第 4 編 \\ 腫瘍性腹水の細胞学的研究 \\ 附. 全編のまとめ \\ 周山大学医学部平木内科教室（主任：平木 樑教投） \\ 嘉 村 淳太 \\ 〔昭和 34 年 12 月 24 日受稿〕
}

目次

I. 粕 言

II. 银察材料及び観察方法

III. 斛察所見

1. 細胞構成

8. 湭湧細胞の出現率による分類

3. 陲晹性腹水の直接徽候

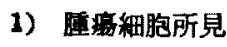

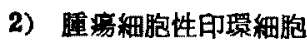

3）各㮔腫婸細盷の形態学的特性

a) 胃癌細胞
i) 腺癌
ii) 単純䌿
iii) 硬性癌
iv) 膠様㾇

\section{I. 粕言}

前糄に於て腫演性以外の突患腹水に就てその緗胞 学的特衙を検討し，夫々の突患に忘じて特異性のあ る事を知り，この特徽を観察する事により疾患診断 に十分役立たせ得るあのである事を迹へて来たが，

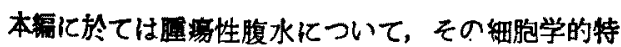

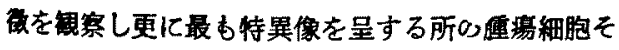
のあのについても検討する事とした。

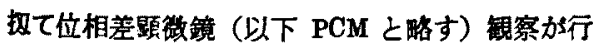
われるようになつて以来重痬細胞もまた観察の好材 料として取上げられている所であり，動物実験によ

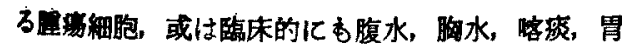

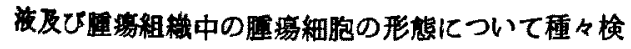
討されている所であるか，Zanes(T) 等は嫞人科領域 に於て200例につき稓䋈しているが貫家 ${ }^{36)}$ 6同様婦
b) 肝癌細胞
c) 体腔上皮腫稩胞
d) 細網肉䏸

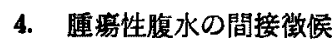

1) 緗胞構成上の特徽

2) 細胞学的特徽
a) 食紲胞
b) 㳫膜細盷
c) 好中球
d）印愛細胞

IV. 紷括及び考按

V. 結 論

附，全編のまとめ

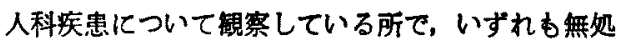
理のまま見られる事の有利さを強調している，又 von Albertini4) は種々の癌について観察し夫っの 癌細胞の特徽を举げている。稻垣 ${ }^{30)}$ は肺癌患者に ついて喀瘀，胸水等加ら痹細胞を検出しその特徽を 報告している，Zollinger ${ }^{78)}$ は動物睡湯細胞につい

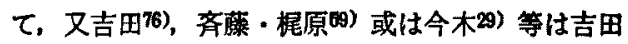
肉連について生態観察所見，更にその楽物添加所見 等を報告し, 又武田662は種々の㢆湯細胞の分裂像 或は核小体等の镦細構造について報告している，山 田下)は種々の材料について癌細胞のみを集める ことを試み観察している. 綾部8), 黑川42)，福 田(保)13) 等は胃液或は Abrasive Balloon 法等に上 る胃癌細胞を瀵察している，その他多数の学者(8)55) により㿋細盷の形㮩については種々報告されている 斦てある。しかしこれらは癌細胞そのものの特徽を 
㳯太

锶察しているのでおり，従つて癌組樴中の痘細胞が 多い，之に反して患者腹水については案外に少く，は 武田はその成書中に於て, 胸, 腹水よりの癌細胞の 猃断について他細胞と比較した特徽を記载している か，他の知患腹水との関係は全然触れていない，千 田・中49)60561)62）はかなりの腹水症例沉つて観察 し，癌細胞，永膜細肘等の所見け相当詳しく検討し ているが, やはり全体として珫一されていない点が あり，腹水矣患診断法としては不十分である．山田 あ腹水を材料としているが癌細胞を集める方法に主 力を置いている，従つて私活癌絟胞追体の観察活勿 諭の事であるが，それだけでなく食級胞等の他細胞 の所見も詳細に穓察し, 連湯性腹水全般についての 特徽を求め, 前編につつき突患艦別法に役立たせん と試みた次第である，即ち腹水中に腫演細胞を矿認 出来る際论診断としては極めて容易となる。このた めに畽雾細胞所見を十分承知していなければならな いととはいうまでもない．しかし時に腫浣緗胞の発 見され婸合があり，かかる際堭煌性とすべきか否 かは大に問題となる所である. かかる場合腹水中他 細胞に何か特徽があれば猃断に大に参考になるとこ ろである。

そこで前編に於て他突患について㮰察した所見を 参考とし，埂演細胞の出現の見られる場合を直接往 侯と呼ぶ事とし，乙の場合の食細胞等他細胞の特徽 を概察し他疾患とは異る特異所見のある事を確認し 得たので，この所見を基として腫場細胞の锶察され ない場合もかかる所見が見られる時は間接衠候陽性 とする事として隀缹性を疑うべきであるとした，以 下こ机等の所見を述へる事とする。

\section{II. 筧察材料及ひ覞察方法}

前編に於て報告したと全く同槏である，即ち材料 としては患者腹水でてれを遠沈沈股1000回転 5 分間 行い，ての沈楂を僅かに上清を残してよく混和し， その沈泾液を良犋スライドグラス $(0.9 \sim 1.0 \mathrm{~mm}$ の厚さがよい）上におき，カパーグラスを被せパラ フインでその周囲を包埋する．ての際の㭚冒は多す ぎると湓出し, 䋖胞は重層し, 又流動するので観察 し難く, 少なすきると気泡が入り, 又任迫されこれ 又見苦しい，従つてなるへく細胞が単首に亚びしか も圧它变性をおこさない程度の量がよい，レンズは 細胞全体の比较, 顆粒の光煇性等の観察には BM, ミトコントリリア（以下「ミ」と略す）等の微細構造 を钲察するためには DLL, DM を使用した。用に
臨み $37^{\circ} \mathrm{C}$ 保温箱中にて観察した。鹳察時間は標 本作製殆んど直後より変性するまでで，大体12時間 乃至24時問観察し得る.

\section{III. 锶察所 見}

\section{1. 細胞構成 (第 1 表)}

样成紒胞百分比を観察したのは20例である（他に 十数例細胞の観察のみ行い細胞百分比を算出してい ない症例もある).

腫瘦細肘の出珼率は 0 48\%の大なる開きがあり，

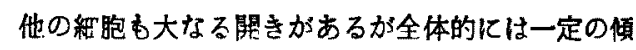

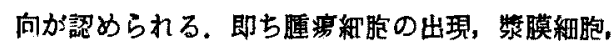
四環紒胞（埂演紶胞性及び食細肘性共に）及び好中 球の增加が認められる. 赤血球については㢆瘦細胞 の出現するものでる，殆んど認められないるのを20 例中 2 例認めている。

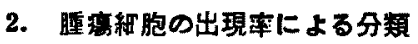

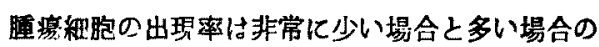
両栖端で私の例で最高47.5\%，最低0\%である. 出現を見ないものは後述の間接徽候により診断し， かつ剖検或は手術により確かめられたものである. そてで出現率 5 96以下を第 1 群，20\%以上を第 2 群 としたか，第 1 群は胃癌その他による腫湯性腹水で あり，第 2 群は癌性腹膜炎之体肱上皮腫による場合 であつた．この他肝癌では癌細胞は特異の細胞所見 を呈し，かつその出現率む不定のため第 3 群とした。 以上各群の物理化学的諸性:状及び生体染件新は教 室小烃原41)により, 又組織培養に於ける明視野頙

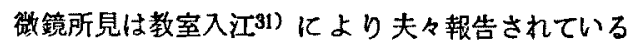
所である.

\section{3. 腫珪性腹水の直接徽第 2 表)}

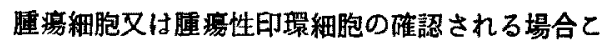
れを直接徵候と呼ふ: 事とし, 腫韵細胞以外の綀胞学 的特性を問接微候とした。ただ一個の腫裙細胞です 確認出来れば直接㣲候であり, 䧐断は直ちに決定出 来るが、このため癌細胞であると決定するには極め て慎重にその細胞学的特徽を検討すへ徉である. こ のため腄演細胞の所見を観察するにあたり，前述の 文献を参考とし，又教室入江，小松原の所見を参考 とし明確を期した。

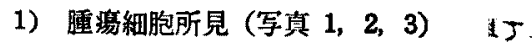

一般的䐈㻛細胞所見を述べる，先ず細胞の大小 不同が強いがー般に大型で, 又胞体全体として密度 高く厚味がある. 胞体縁は極めて明瞭に培地と境さ れる. 細胞自体としての通動は認められないが胞体 


\begin{tabular}{|c|c|}
\hline & 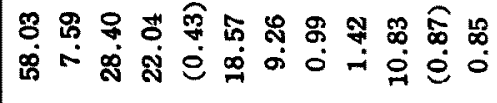 \\
\hline న్ & 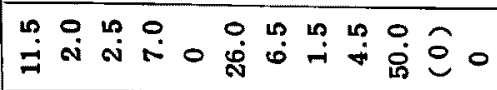 \\
\hline 9 & 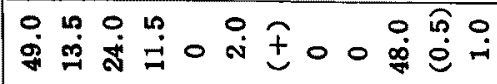 \\
\hline$\stackrel{\infty}{\mathscr{\infty}}$ & 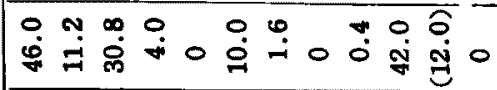 \\
\hline$\approx$ & 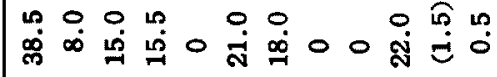 \\
\hline$\stackrel{9}{0}$ & 只 \\
\hline$\Rightarrow$ & 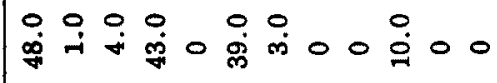 \\
\hline 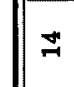 & 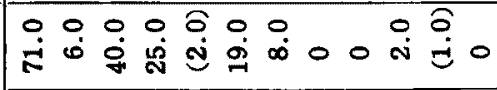 \\
\hline$\stackrel{m}{\rightarrow}$ & 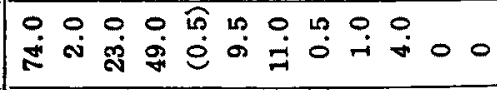 \\
\hline $\mathcal{y}$ & 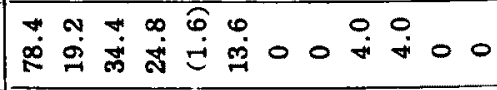 \\
\hline$\vec{F}$ & 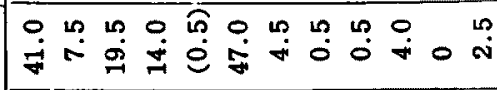 \\
\hline 우 & 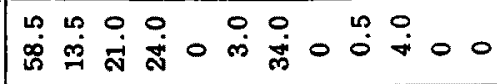 \\
\hline 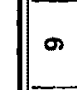 & 兑 \\
\hline$\infty$ & 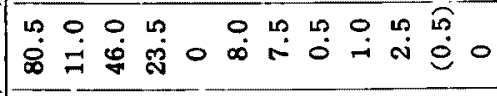 \\
\hline 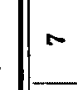 & 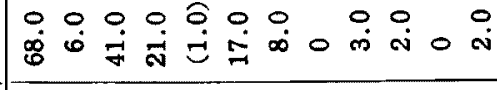 \\
\hline 0 & 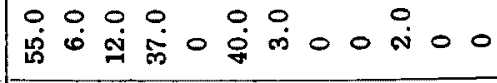 \\
\hline in & 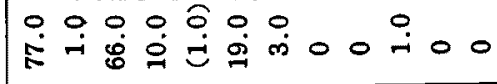 \\
\hline 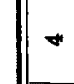 & 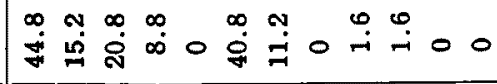 \\
\hline m & 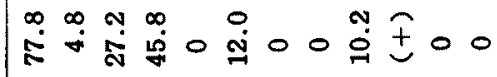 \\
\hline $\mathbf{N}$ & 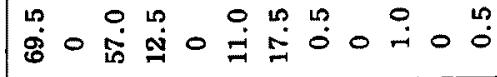 \\
\hline 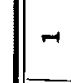 & 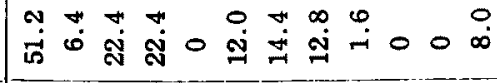 \\
\hline 胥 & 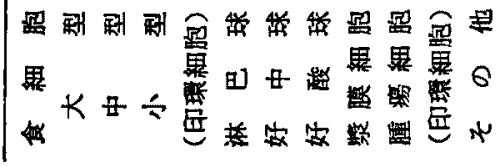 \\
\hline
\end{tabular}

第 2 表 腆湯性腹水の特異所見

\begin{tabular}{|c|c|c|}
\hline $\begin{array}{l}\text { 直接 } \\
\text { 徵候 }\end{array}$ & \multicolumn{2}{|r|}{ 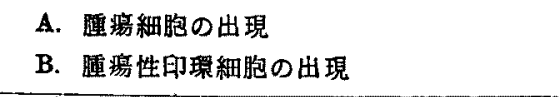 } \\
\hline 間 & 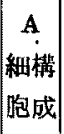 & 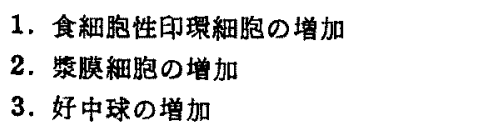 \\
\hline 碚 & $\begin{array}{l}\text { B } \\
\text { 食 } \\
\text { 細 } \\
\text { 胞 }\end{array}$ & 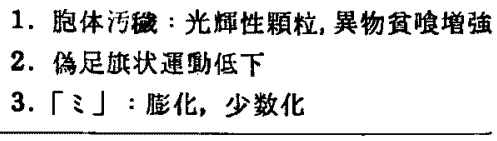 \\
\hline 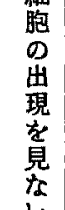 & 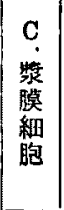 & $\begin{array}{l}\text { 1. 出現率平均 } \\
\text { 2. 偽足運動微弱 } \\
\text { 3. 光輝性顆粒增扣 } \\
\text { 4. 「ミ」短桿状化 } \\
\text { 5. 核小体や小不揃 }\end{array}$ \\
\hline 場 & $\begin{array}{l}\text { D } \\
\text { 好 } \\
\text { 中 } \\
\text { 球 }\end{array}$ & $\begin{array}{l}\text { 1. 出現率平均 } \\
\text { 2. 運動不活涭 } \\
\text { 3. 鼔化変性高度 }\end{array}$ \\
\hline
\end{tabular}

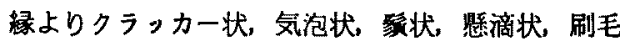

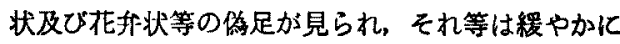
出没するものから，かなり活発化伸寉するまで多様 である．胞体内に大小不同で光輝性す不同の多数の 顆粒を認めることが多く，又空胞す多い。これらの 空胞は食紐胞の6のとは異り屈光性がやや強く, こ ロイド様のものが多い．「ミ」は微細柆状，短捍状 のものが多く，数も多く散在し集旋性は見られない。

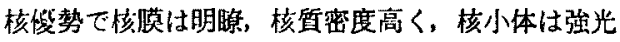
辉性, 大小不同強く, 又形態も多棣であり $2 \sim 3$ 個, 多い時は $5 \sim 6$ 個も認的られる. 時間と共に変性す

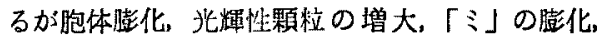
核萎縮という形式のものが多い。

\section{2) 腫漩細胞性印環細胞}

腫場性印環細胞は前編に於て述へた食細胞性印環 細胞とは異り腫湯細跑性格をもつものである，即ち 盷体縁（印環壁）厚く培地と明確に区別され传足は 殆んど見られない，印䅫内容の大空胞はやや培地上 り屈光性強く，釷く光り，又小空胞は重り合い立体 的で，核は一方に押しゃられるが核膜はなお明瞭で，

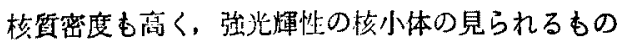
加多い.

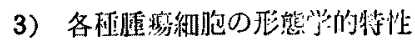

a) 胃擖細胞

i) 腺癌 (写真 4)

細胞の大さは大小多様で姿々集団細胞として花冠 状形成や癌紧形成をなす，原形斦の巾広く，密度高 
く、やや小さいのがかなり揃つている中等度光辉性

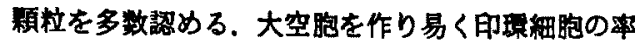
高い.「ミ」は顆粒状，短桿状で数は幾分少い。 核は扁在（核比で最す小），類円形，核膜厚く，核 質密度高く、核小体は大小不揃いなるる全体として はやや小となる，互に速り合つているため珛足の出 現は少い。

\section{ii) 单純癌 (写真 5 )}

やや大型，盷体緑明膫なるるクランカー状，愁滴 状等の偽足の出現が善明で，胞体整度高く，核胞体 比は中简的で，やや粗大中等度乃至強光輝性顆柆を 漂漫性に認める，空胞はやや小さく数も少い，「ミ」 は微科顆柆状，双球状の6の加多く，数も多くほほ 均等に分布する。一見して跑体が污理という成があ る. 核はほほ中央に存在し類円形，核膜厚く核質密 度高く，核小体は最す大て大小小不同あり，形も多様 性が強い，分裂像す多いか涷結して花冠形成をなす ような事は少い。

iii) 硬性癌 (写真 6 )

細胞は小型で円形，従つて核る小さいが核比はや

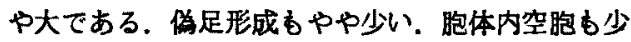
く，光輝性顆粒むやp少く加小さく，「ミ」は微 細顆粒状で核周にやや密である，甲環細胞化す稀で ある. 核瞙厚く，核㨁染度高く，核小体仕北煇性強 く大小不同性も強い。

\section{iv）䀩样㾇}

腺癌に多数見られるあので，胞体は全くコロイド 状で中等度強光輝性の班をなし，顆柆はなく核は消

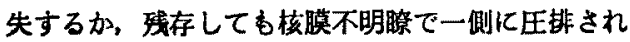
ているものが多い、「ミ」る少数残存するすのは核 周に散在しており，全般的には消失しているるのが 多い。时環細胞化も著明となる。

\section{b) 肝癌細胞}

大型加多く，胞体優勢にて特異な粗大中等度乃至

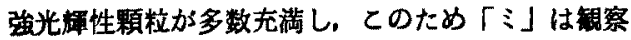
し難い，又核む十分に観察され難くなる，印環細胞 化せず，運動性も少い。

c) 体腔上皮嗹稩胞（写真 7，8）

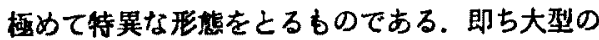
ものが多く，形態は多様性で中には巨大なむのも見 られる，一般他他の癌細胞に比べとやや扁平感が 強く原形啠密度す低い，一個分離しても見られるが， 二個或は数個又多数のものが集団をなして山現する 場合加多い，しかし平板状に搪がるもので腺構造を 作るような事はない，原形犋内に大小不同の強光輝
性顆柆を多数認め，空胞も多数見られる.特に大顆柆、 大空胞の見られるもの等あり極めて多彩である. 「ミ」は顆粒状，双球状或は短悍状とあり，多数で 核周比やや留に存在する，核付類円形のあの多く， 核膜明瞭で，核啠密度も高く，核小体は核に比しゃ や小であるが形䈍は多様である．印環細胞様となる ものも多く印環細盷とならぬまでも大空胞化するも のが多い，伪足は極めて多様多柇でクランカー状，

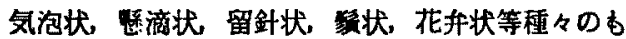

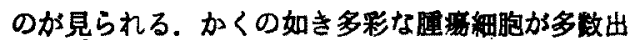
現してくるが、てれ等を詳紐に勧察すると少数では あるが極めて繁膜細胞と類似するるのか見られる。 即5月形で光輝性顆粒少く，「ミ」の獎膜細胞槏同 心円状の排列加見られるか，「ミ」は粒状，哣捍状 で数も整膜細胞より多い，核犋密度も他の腫痬細胞 に比してやや低いか，核小体の形態が多様である事 で整膜細胞とは区別し得る。

d) 細網肉腫 (写真 9)

前述の癌細盷飞比すと扁平感つよく，胞体密度も やや低く，胞体绿もやや不朋膫となる。特有のほほ 同大の強光煇性，円形の顆粒を認める. 恐らくリポ イド滴之思われる. 空盷は少い.「ミ」は短桿状或 はやや長目となり，数が少く，核周にやや多い，核 は類円形或は腎形て核膜は明瞭なる癌細胞に比す とやや薄く，やや分葉㑯向のあるあのあある，核椞 密度も低い，核小体は明瞕，中等度光帮性で多形性 つ上く，中には地四様汇核網結節の強く光るものか～ ある.

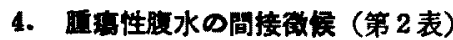

上述の如く重場种胞の確認出来ぬ場合，細胞檴成 及び各種細胞の性格を特性つけるととにより，てれ

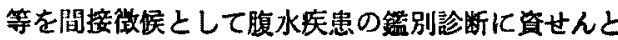
した.

1）細胞㛵成上の特徽

細胞構成百分比注個々の例では相当の差加あるが， しかし全体を通して見ると次の如き傾向か認められ ろ. 即ち䟿膜緗盷の增加，印環細胞の增加，好中球 の増加等である．なお赤血球はやはり殆んどの例に 於て多かれ少なかれ認められた所であるが，しかし 殆んど惩められぬ例（20峢中 2 例）もあり，赤血俅 を喼めぬため腫湯性でないという事はいえない，

2) 細胞学的特嗮

a) 食細胞 (写真10)

中型或は大型が多く，胞体緑は不明暸なるる。偉足 突出は少く，極好て大小不同の不揃つ光煇性顆泣充 
满し，異物会喰も多く，大小不同の空胞6多く，両 者共に混在し，「ミ」は認め難く或はやや腿化梗少 数となる，核は萎樎し，核膜やや厚く，核質密度も 大となる，従つて全体として污粪である。

b) 膜細胞 (写真11)

胞体は円形，類円形のもの多く，胞体緑は明睹， しかし多角形或は数個連り合うものあり，胞体内に やや不揃の中等度光煇性顆柆の出胃あり，特に大な 万強光竨性顆粒あり，「ミ」もやや短く，短桿状の ものが多く，運動すない，核は円形，核啠密度やや 高く，核小体もやや不揃いとなる，時には多核性の るのあ見られる．偽足運動は始んど見られない，即 ち肝硬変の場合に比し細胞機能やや低下していると いえる. こ机らを巽型漿膜細胞と呼ぶ事とする。

c) 好中球 ('写真12)

一般に変性早く胞体は膨化しているものが多く，

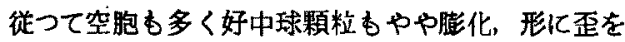
生し，强光輝性の変性顆柆。多数生してくる.「ミ」 も脚化し数もやや减少してくる。核は浱縮し細胞の 中心部に集るすのが多い，従つて遊走機能も低下し $\tau<る$.

d) 日環紐胞

食細胞由来のものも偽足突出が少い.

\section{IV. 総括及ひ考按}

私は PCM を用いて 1，2 編では各種動物及ひ人 非病的腹水について問題となつている所の食細胞の 本悲について検討し，てれが組織球ではなくて単球 近縁のあのである事を述へ，続いて 3 編では臨床編 として患者腹水について検尌する事とし，腫場性腹 水以外の各突患腹水についてその稩胞学的特徽を報 告した所である，そこで本編では残つた所の腫境性 腹水について観察し，腫㻛細胞はしめ各緗胞の特徽 を比較検行したものを述へてきた。

緒言で述へた如く隀需細胞そのものの PCM 勧察 はかなり多数の学者により報告されている所である。 しかしてれ等の啹告は腫湯細胞個々の性格のみを対 象としていて，知患企体特に鑑別猃断という点は殆 んど顧みられていない，そこで先ずこの腫䁑細胞を 更汇詳しく検討し，腫瘍細胞（腫痚性印環細胞を含 む）の出現している埸合を直接裳候ということとし，

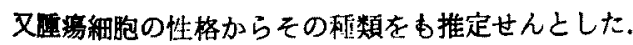
次で食緗胞の性格など他緗胞についても穓察し，畽 演性腹水に特異所見のある事を認めたのでこれを問 妾徽侯と呼ぶ事とした。

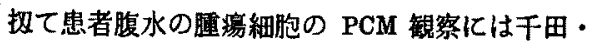
中52，武田66)，山田节）等の報告があるが，この中, 山田は腫㻛細胞を集めるということに重点を置いて いる. 私の所見も全般的にはとれ等諸家と大差のな い事を認めるものであるが，武田によると癌細胞の 「ミ」が少く肉腫細胞の方に多いという印象を受け るが，この点逆に癌細胞の「ミ」は粒状等に断裂し た如くで多数認められ，肉嗹細胞（細絧肉腫細胞で あるが)ではやや長目で数も少いという所見を得た。

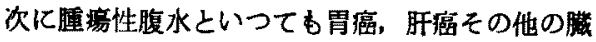
器腫瘍からおこり得るものであるので二，三の癌細 胞について詳しく比較して見た処，胃癌練胞の中で も腺癌, 単純癌, 硬性癌及び閭粎癌に夫々異る所見 のある事が認められた．細胞の大きさは硬性癌が最 あ小さく，腺癌, 単純虞はやや大きい. しかし腺癌 は殆んど同大で集団をなし癌巣をつくり，腺構造， 花冠形成をなすの加多いか，算純癌，䃘性癌は一 個づつ分離独立しているあのが多く，従つてやや 大小不同である，硬様癌はお互に連り融合しあつた ようになる. 光焷性顆粒も硬性癌, 単种癌, 腺癌之 いう順に增加し，硬様痹は全くコロイド様無構造で 屈光性に斑を生している程度である.「ミ」は硬性 癌では微細多数で核周に多く, 単純癌す絧多数で あるが双球状のむのあ多く胞体全面にほほ均等に散 在し，腺癌はやや大型となり数あ減少傾向にある。 賿様癌では「ミ」は殆んど消失しているか，おつて あ少数で，核の観察される場合はその周辺に見られ る. 空胞は腺癌に最も著明で大空胞化し时環細胞粎 となるものが多い，他は少数で大空胞は少い，核は 夫々細胞の大きさに準じて大小があるか，核胞体比 では硬性癌が最も核偠勢で単紨癌が之に次ぎ，腺癌 は胞体比が最も大である、賿㥞癌は核は圧排され、 殆九ど観察され難くなつてくる，核啠密度，核小体 の形状はほぼ同様である。

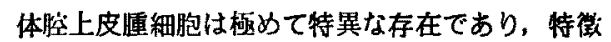
的で一見して判別されるようになる. 即ち大きさか 巨大なものから小なるものまで大小不同か強い，又 一個のもの或は多数連なるるの等多様で空胞形成も 強く，印摆細胞化す著明である．多数連つたあのす 腺構造を造る事はなく，膜状である，又伪足が極め て多彩て色々な形のものが見られる。特汇叢状の伪 足が一側にだけ見られるのが特有で細胞間結合系の 跡加之思和る。一般に空胞变性化加強いか，詳細 に観察して行くと中に極的て㢣膜細胞に近いもの即 ち胞体円形で空胞少く，「ミ」が同心円状排列をな 
しているものを見る.しかしてれあ「ミ」は短棉状 で断裂したようで，細い糸状のすのは胃られぬとと， 校小体比大小不同あり，その形態の不同性す強い事 等でやはり病的なる事がいえる. 教室浅香7はとの 体腔上皮腄腹水をローラーチェーブ法で長時閒培盖 しその経過を見ているが，との所見によると培 4 〜 5 日で細胞は変性し，新たに分裂新生せる小細胞 を多数認め，しかもとの新生細胞は極的て等膜細胞 飞近いものであり，とれが又膨化変性或いは分裂を 絽り返す事を珰めている．との事からす体腔上皮腫 はその母体が管膜細胞であり，これが腫痛化したも の上云い得る。

次に細網肉隀細胞は癌細胞とは又異つた形をとる. 手術時摘出甘る組織像が細網肉腫でての患者に腹水 を生じたものであるが，この細胞は全体としてやゃ 軟かく滑らかで，胞体内に強光輝性リポイト滴と思 われるものを数個〜十数個認めるのが特巽である. Ackerman1) は淋巴肉盾細胞に於いてではあるがリ ポイド滴様の存在が特異で淋巴乎球と区別し得る点 の1つとしている. 教室柴田61) は吉田肉腫綀胞に 於いてす同様のリポイド様滴が出琴する事を報告し

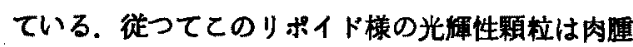
細胞に特有のあのかと思われる.「ミ」あやや長目 となり数も少なく核陥凹部に多い，とれ又柴田は吉 田肉庫細胞についてゴルヂ野を中心として放線状に やや長目の糸状の「ミ」の存在する事を認めている が、私の細網肉腫細胞の揚合あとれ等に近い所見で あるのて，汃くの如き「ミ」の所自す肉連細胞に特

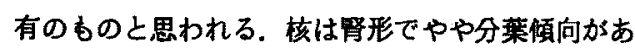
り，核膜もうすく，核小体は明瞙で，大小不同性及 び形㦔の不同性が強いが中には核絧䊀節が地図模様 に強光蛼性をなして見られるものあある。

次に今一つの直接徽候は嗹湯性问摆細胞であるが， 时理細胞には他に食細胞由来のあのあある事は 3 編 に於いて述へた所である，そこでての両者を比校し て見ると，睡場性印環細胞は細胞化大小不同あり印 環壁が厚く重厚佂あり，伪足突出なく，空胞多数の 時位立体的化重晾り合うものが多く，内容の屈光性 も強くコロイド状であり，又核膜明膫で核小体む明

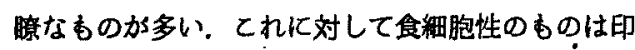
環壁うすく，偽足を触手状草状に笑出し，印橿内容 も水様で屈光性弱く，核膜は不明瞭で核小体は䛱め られないので前者々は区別される．教室入江 ${ }^{31) は ~}$

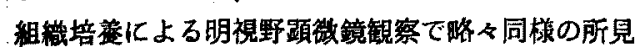
を認め，又小松原41)は生体染色，藇粒会喰所見で

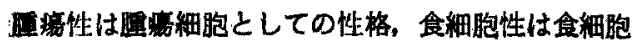
としての性格を失つていはい事を認めている.

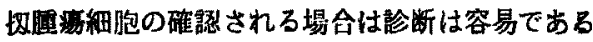
が、認められぬ場合影断は植めて困難となる。 こて

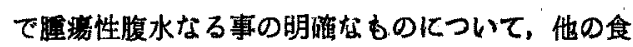
細胞等の細胞について詳細に観察した処，他の諸疾 患の場合と異る特徽を示している事を認めたので， とれを間接徽候と呼ふ事とし，腫灌細胞を認めない 腹水でもこれら間接徽侯が揃つてくれば腫瘍性を疑 うべきであるとした．先ず食細胞について見ると一 見して非常に污穠である．即ち大小不同の光輝性顆 粒或いは大小不同の空胞が充満し「汭は殆んど 認められなくなる．核は萎縮し顆粒に嗄われて観察 され難くなる，次汇等膜細胞であるが，矢镸り肝硬 変に見る如き細胞即ち胞体清明で，「ミ」あ系状に 伸び運動性も見られ，胞体も変形し運動能の高い細 胞は殆んど見られなくて、変性に近いすのがみられ る. 即ち胞体に光輝性顆柆多く、「ミ」も断裂した ようになるか或いは刺戟状態の如く形態が多様で集 団をなし，核も偏在し，核小体の大小不同やや強い 異型瀪膜練胞とも云うへさすのが出現してらる. 好 中球は混合感染を起したすの或いは库性は別である が，一般に変性が早く運動性る少ない，又食細胞性 印環細胞它やや增加しているが，乙の腾足突出も幾 分少なくなる，以上が間接徽候であるが教室小松原 は最近 TPT 反応を行ない非腫癌性腹水の食細胞は

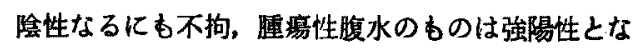
る事を認めている. 又食細胞の墨煜貫喰能も他疾患 腹水比比して強く，その他繁膜細胞の生体唯色性の 穴進，好中球の生体染色性の亢進 認められている か，乙れ等を参考とすると間接徴候による診断も一 層確実なものとなるわけである.

最後に腫湯性腹水を隑瘦細胞出現率により第 1 , 2,3 群と分類したか，乙れ等の間に於いて細胞学 的には大差か認められなかつたか，物理化学的又生 体然色，鹠粒頜喰等の幾能的な面化は加なりの差の ある事か教室小松原により認められている、この中 第 1 群の如く腫場細胞を認めぬか或いは極少数に認 めるものでは，物理化学的性質す湍出性であり，従 つて肝硬変症との区別が困難となる，しか心近時と の二矣患による腹水詝溜が最す多いものであるので 上述の間接街により比较して見ると次の如くであ る(表 3 ). 先ず食細胞ては, 肝硬変では中型多く。 胞体清明で，しがあ単球様運動或いは更に長大な偏 足を突出し䌅やかではあるが若草の萠ゆる如き遇動 


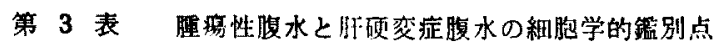

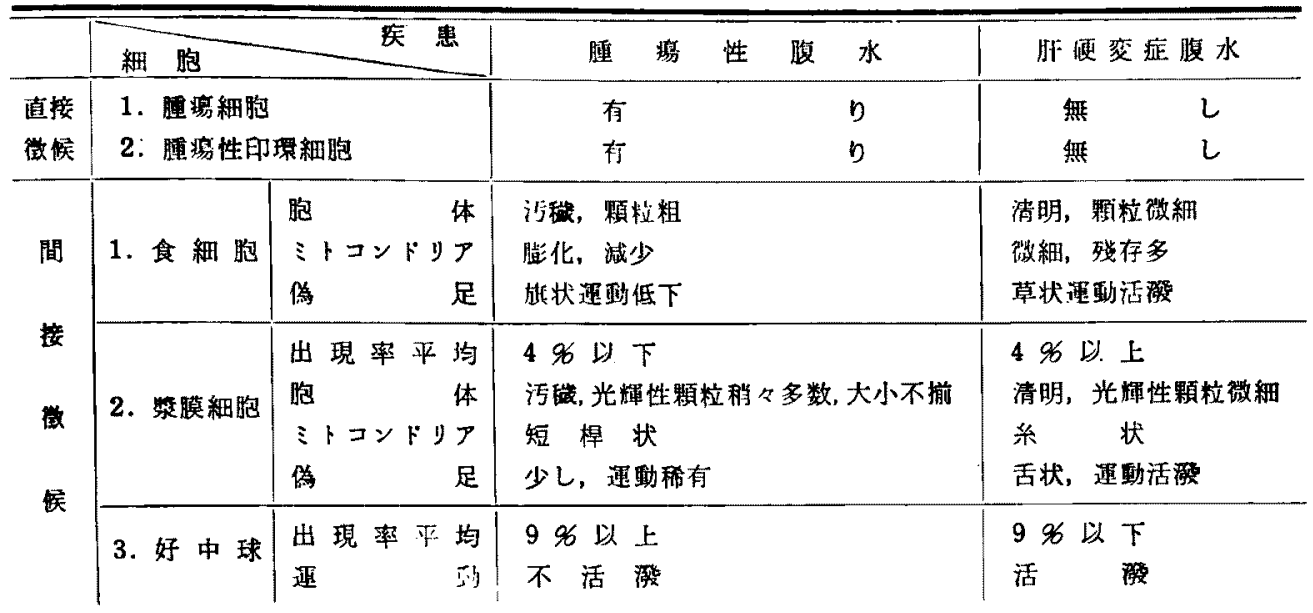

をせしめ，「ミ」も徽細て単珠様排列をなすものが 多い，又核の立体感つよく複雑な形態を示している。

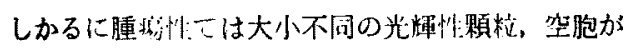
充満し異物会喰も強く一見して污なく，又俭足運嶓 ち殆んどない，「ミ」はやや膨化するか或いは認め られなくなる，核は萎縮し平面化し，核質密度は高 くなる，次に瀪膜細胞については，肝硬変では特有 の形態をとり蝴蚪状等に伸びるむのもあり，伪足運 動活澄で半月状，舌状の偽足が出没し，或いは瘤状 になるものあり，胞体は清明で円形のものでは「ミ」 の同心円状排列がみられ,形の伸びたものでは「ミ」

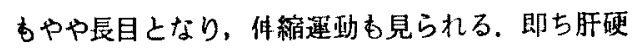
変の漿膜紐胞は正常状態での機能六進を示すすのと 云える.腫瑒性では胞体は円殁或いは多形性で集団 的㑯向強く，偽足運哺なく，光輝性顆柆をかなり認 め,「ミ」も短く断裂した如くで運動も行なわず， 核も看在し又核性のあのもあり，核小体もやや不規 則となり，要するに異型漿膜細胞とも云い得る細胞 である，好中球は肝硬変では出現しても形怎，運杪 能共正常（血液中之同粎）に近く，会喰等の機能 す正常に近い，腫場性では川現多く996以上に見ら れるか，譏能としては低下し胞体膨化，核萎縮と云 う变性像が強い，印環細胞は肝硬突ではむとより食

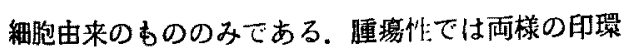
細胞かみられるが食細胞性のあのでる偽足突川等少 なく変性傾向が強い。

第 2 群は緗胞数多く，物理化学的性質る炎症性で あり，一応結核性腹水との区別が問题となる。しか し絧胞学的には明らかな差が認められる。即ち結核

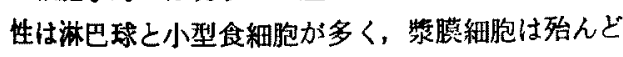

なく，好中球も少なく，印罩細胞も殆んど見ない。 食練胞の胞体清明で，「ミ」あ单球様排列をなす。 腫湯性てはもとより腫演紐胞が先ず見ら扎る事で区 別されるか，その他細胞楛成及び構成細胞の性格即

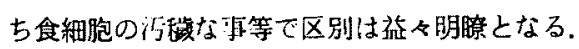

ネフローゼ腹水, 心臟性疾患によるものとも区別 すへきであるが第 3 編の所見を参考にすれば細胞構 成，構成細胞の性格から区別は容易である。

以上総括して述べて来たか，かくの如き方法によ る疾忠略断法は前述した如く他に殆んよ゙類を見ない あのである。即ち只腫㻛細胞そのものだけに就いて の PCM 所見は従来相当詳勫に梌㳔されているか力疾 患診断と云う点に於いては全く不統一で直結してい ない憾かすつたのであり，ての点他の細胞も含めて の細胞学的効断は腫煬抄腹水の診断のみならず，他 の腹水智患との鑑別郝断と云う点に於いても極めて 有力な万法であると確信される次第である。

\section{V. 結論}

第3編にひき続き PCM を用いて，臑淿性腹水に 就き腫瘍細胞の観察のみならず，食細胞等他の細胞 に就いても㓋察し，次のような舆味ある所見を得た。 1. 腫湯細胞の泪率により 5 \%以下のものを第 1 群とし，20\%以上出琾寸るるのを第 2 群とし，不 定の6のを筑 3 群とすると，胃癌性腹水，㾮性腹膜 炎，肝福性腹水がそれぞれに属する。

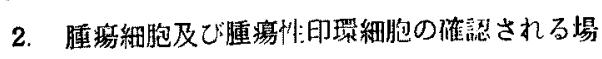

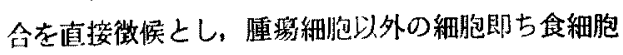

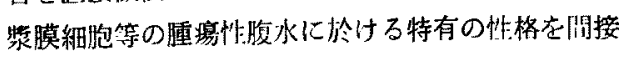
徵侯と呼ぶ事とした。 
3. 睡痛細胞それ自体すその種類によりそれぞれ

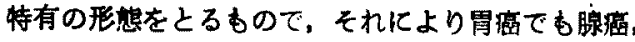
単純癌，硬性癌，膠様癌とそれぞれ区別し得，又体 腔上皮鲻細胞は更に特有の形を呈し摮膜細胞之の移 行像も見られ，肝灌細胞には特有の顆粒あり，又細 網肉胴等の肉腫細胞は癌和胞之は異つた所見を示す、

4. 間接徽侯に就いて見ると食細胞は一見して污 湠であり，繁膜細胞は变性㑯向強いか或いは異型性 が強く，好中球も変性が早い，乙れらから肝硬変， 結核性腹膜炎等の他疾患之の鑑別が容易に行ない得 3.

5. 第 3， 4 編を通じて，腹水の細胞学的診断は

\section{全編 のまとめ}

腹水細胞の研究は古くより先人により検副されて いる所であり，就中その大部分を占める食細胞につ いて，その本態が単球系なるか組織球なるかが論境 の中心となつていて，今日尚大なる論争を呼んでい る所である。しかしてれまでの諸家の方法は，死後 杂色或いは超生体染色と云う方法であり，とれらの 方法は変性が早く，細胞の鑑別には不十分な点が多 い，そこで私は近年盛ん便用されるに至つた，位 相差影镜鏡 (PCM) を用いて腹水細胞を観察し， 特に食綀胞については詳細な吟味を行なつた，PCM は細胞を生きたままで観察出来，しかもその改細構 造を観察し得るもので, 細胞学の新研究にはなくて はならぬあのである．方法は圧挫法とした，又てれ らの所見を基として，臨床的にも応用せんとして， 患者腹水を観察し，その細胞構成及び構成細胞の所 見より，矣患猃断を行なわんとした。

先ず第 1 編では正常犬，猫，家鬼，ラッテ，マウ ス及び家筃の各㔖物及び非病的人腹水について観察 した. 各動物とも細胞構成の主体をなすすのは食細 胞であり85\%以上を占めている. マウスでは食細胞 は単球と組織球との両者の性格が見られるものであ ろか，ラッテ，家兔，犬，猫と高等になる程単球様 性格が強くなり，特に犬，猫では全く単球と区別出 来なくなる，ただ運動のみ緩漫であるが，その運的 形態は全く単球様なる事は纱面撮影炕つても確認 している，運動の緅漫なる事は，腹水と云う特殊環 境に対する環境遒応によるすのと思われる，人非病 的腹水食細胞は数少なく，やや变性したものが多い がそれです細胞学的には全く単球類似のるのと云
諸㮔腹水の臨床的鑑別趁断上有力な手段となり得る 事か明確になつた。

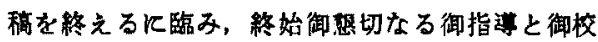
閲を睗わつた恩皈平木樑教授立びて大藤真助教授に 心より深謝する。

（本論文の要旨は第19回日本血液学会総会，第12 回日本内科学会中国・四国地方会，第44回日本消化 機病学会総会，第 4 回臨床病理学会中国・四国地方 会並びに第 2 回岡山地方释交見会飞於いて器表し た).

\section{える所見を得ている。}

第 2 編ではこれ等食細胞の本態を更に詳細に検討 する為マウス皮下組織球，マウス及び家鬼腹胵内刺 戟時の食細胞の細胞学的変化及びその際の皮下組蟣 特に皮下組織球の変化について観察し,ついでマウ ス血液単球更汇人血波単球の腹水添加組織培意時の 細胞学的变化等を観察し比較検討した，マウス正常 皮下組織球は鋸每状緑，光辉性顆粒の多数均等分布、 「三」の均等分布，核平面化，核小体明瞭なる事等 で腹水食緗胞之区別せられ得るものであり，刺戟時 腹水では小型食細胞の増加し，荤洏性も亢進し，又 単球そのあのと云つてよい細胞の增加等汃見られ。 との際の皮下組織では，皮下組織球はそのまま留性 して行き，単球嵄変化は認められない，ママウス単球 あ人単球や家兔単球に準ずるものであり，人単球を 腹水添加組織培意により長㭙間観察すると，胞体は 硬く，光輝性顆柆增加し，変性過程として食細胞化 する所見が得られた。

以上第 $1 ， 2$ 編の所見から腹水食細胞は単球近縁 の細胞と云わざるを得ない。

続いて第 3 編では上述の所見を基として臨床的に 患者腹水に就いて短察した。忠者腹水でる構成細胞 の主体をなするのは食細胞であり，しかもこの食細 盷は一廉単球的所見が強い，又咏膜細胞が笑患腹水 では多かれ少なかれ諗められるもので「ミ」の系 状で同心円状非列, 同大同形の核小体等極好て特買 像を呈する事が認められ，揪患により形態学的変化 があり，矣患訅断の根拠ともなり得る䯅が明確とな つた. 
肝硬变では食紐胞は変性少なく，若草の萠ゆる如 き侸足運動をなし，食細胞性印環細胞を多数認め， 永膜細胞も多数出現し荤動も盛んである，結核性腹 膜炎では細胞数が最も多く，小型食細胞と淋巴球が 王倒的で，食細胞の運预性の亢進がある。

ネフローゼでは大型食細胞が多くしかす大空胞を 6つあのが多い.

心煘性疾患ではネフローゼに似るが食細胞の網状 膨化が多い。

最後に第 4 編では腄場性腹水に就いて観察した。

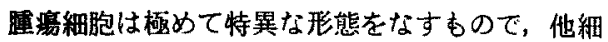
胞とは明確に区別し得る。この腫境細胞及び腫湯性 即環和胞の出現するすのを，直接徵候とし，食細胞，
獎膜細胞，好中球等の形態加堙瘍性腹水に於いては， 特有の变化が見られる事圶認め, 腫瘍細胞を認めな くても，これ等の細胞の約胞学的特徽の見られるも のを閻接做候とした，又腫晹細胞それ自体む腺癌，

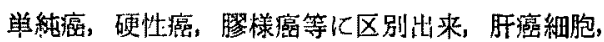
体祭上皮腫細胞むそれぞれ特徽があり，更に細絧肉 腫細胞は癌細胞とは翼なる所見の認められる事を籍 察した。

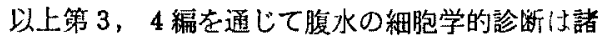
程疾患腹水の臨床的鑑別診断上有力な手段となり得 る事が明らかになつた。

献

25）平田他：日底会誌，33，50，昭18,

26) Hirschfeld, H. : Arch. f. exp. Zellforsch., 4, 438, 1927.

2）赤崎，小島 血液討議会報告，7，121，昭29.

3）赤崎，小島：日本臨床，15，5，昭32.

4) Albertini, A. V. : Schweitz. Zeitschr. Pathol. Bakt., 8, 298, 1945.

5）天野：血液学の基楚(上)，丸羓，東京，昭23.

6) 天野：日血会誌，6，227，㫛17。昭34.

7) 浅香：岡!医会誌，71（772），4541.

8) 棱部: 胃癌の細胞学的診断, 医学書院, 東京, 昭32.

9) Bergel, S. : Klin. Wochenschr., $4 \mathrm{Jg}, 47$, 1925.

10) Cunningham, R.S. Am. J. Phys., 59, 1, 1922.

11) 福田(源) ·岡山医会諗，70，4199，昭33.

12) 福田(正) ·岡山医会誌，70，3743，炤33。

13）福田(保)，川俣他：綜合臨林，6，1555, 炤32.

14）藤田：凧山医会誌， $71 （ 764 ） 1595$, 昭34。

15) Goldmann, E. E. : Verhandl. d. Deut Path, Gesell., 14, 138, 1910.

16）長谷川：日血会誌，15，29，绍27.

17）皇山，长谷川－日血会誌，15，29，明27飞よる。

18）浜崎(幸) 岡山医会誌，431，1281，大14.

19）服部：岡山医会誌，71（771）４257，归34.

20) 平木, 大烮：日血会誌，19，406，四31.

21）平木，大藤：岡四医会婄，68，4号別卷，四31.

22) 平木, 大藤 : 臨休病理, 5,83 , 昭 32 ,

23）平田 . 日血会誌，9，3，昭21。

24）平田他：日血会誌，7，59，䀡18.
27）市川 四国医学雑誌，4，338，昭28.

28）今泉 十全会雑誌，57，2073，昭30.

29）今木 位相差研㠰会誌，6，(10)，6，1953.

30) 稻垣 位相顕微鏡の臨床的忍用, 第 2 版, 医学 害院, 来京, 1955 .

31）入江：岡山医会誌，71（772），4831，昭34,

32）嘉村：日本内科学会䧱誌，46，569，昭32.

33) Kamiya, H.: Beitr Path Anat., 72, 761, 1914.

34）上与那原・日病会誌，15，28，大14.

35）上与那原：海軍軍医雑誌，18，100，大15.

36）珼家：産婦人科領域に括ける位相差顕微鏡の心 用，医学書院，東京，㫟29.

37）清野：生体染色研究の現况及びその検查術式, 南江堂, 東京, 大10。

38）小島，大西 日血会誌，15，339，昭27，

39）小島 日血会誌，20，補用(学会号)，75，炤32.

40) 小谷：成山医会誌，71（762），691，畹34.

41）小淞原：風山医会誌，投稿中.

42）照川, 齐藤: 臨彇と研究，33，529, 昭31.

43) Marchand, F. Handb. allg. Path., 1, 78, 1924.

44) Maximow. A. A Arch. f. exp Zellforschg., 4, 1 , 1927.

45) Metschnikoff. F. Virchows Arch., 113, 63, 1888. 京, 昭27.
46）水平：传相差顕微鏡とその心用，医学势院，東 
47）村田：日血会誌，16，170，昭28。

48）村田：日血会誌，18，38，昭30。

49）中，千田－日血会隐，13，245, 昭25.

50）中，干田・日血会誌，14，20，昭26。

51）中，上田，千田 日血会䞏１6，269，昭28，

52）中，干田 日本畹床，13(3)，289；(5)，687， 昭30.

53）大藤：最新医学，10，2642，昭30。

54）大藤：臨林之研究，33，604，昭33.

55）太田：癌の臨床，3，101, 昭32。

56) Rössle, R. : Verhandl. d. deutsch. Path.

Gesellsch., 19, 18, 1923.

57) Sabin, F. R., C. A. Doan \& R. S. Cunningham : Contrib. Embryol., 16, 125, 1925.

58) Sabin, F. R.et al Proc, Soc. Exper. Biol. Med., 11, 330, 1924.

59）为藤，掩原：位相差研究会誌，2，1950。

60) Seemann, S. Beitr. Path. Anat., 85, 303, 1930.

61）柴田：岡山医会誌，投稿中.

62) 清水: 解剖学雑誌, 24, 6, 昭29.

63）策崎：日血会誌，19，40，昭31。
64) 末永：岡山医会誌，70（750，1291，昭33.

65）杉山：血液及び組織の新研究とその方法, 南江 堂, 東京, 昭27。

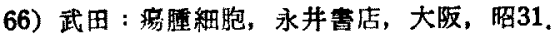

67）玉木他：日血会誌，14，115，昭26.

68) 田坂，富挥：藏器穿刺飞よる診断と治療，金原 出版, 昭32。

69）寺田，日血会誌，16，367，炤28。

70) 白淵他：日病会誌，41，77，昭27.

71) Weidenreich : Verhandl. d. Anat. Gesell., 30, $51,1927$.

72) Weitzmann, G. . Arch. f. exp. Zellforschg.: 22, 414, 1939

73）山近：岡山医会誌，70 (755)，3145，昭33.

74) 山田：臨床病理, 4, 25, 昭31.

75）山田他：日本内科学会雑誌，46(13)，50，昭33。

76）吉田：吉田肉腫一癌化学橖法の基䂣的研究一,

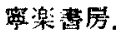

77) Zanes, R. P.: Cancer Resarch, 9, 601, 1949.

78) Zoolinger, H. H. : Am. J. Path. 24, 545, 1039, 1948.

\title{
Cytological Studies on the Aspirated Fluid With the Phase Contrast Microscope
}

Part 4. A ctyological Study on Tumorous Ascites

\author{
By \\ Junta Kamura \\ Department of Internal Medicine Okayama University Medical School \\ (Director : Prof. Kiyoshi Hiraki)
}

\begin{abstract}
As a continuation to Part 3 the author carried out observations on the tumor cells in tumorous ascites with the aid of a phase contrast microscope, and also on other cells such as phagocytes, and obsained some noteworthy results as follows.

1. When tumorous acites is divided into three groups according to the rate of tumor cell appearance: namely, group I those showing less than 5 per cent of tumor cells, group II those showing over 20 per cent, and group III those showing no fixed percentage; gastric cancer ascites, cancerous peritonitis, and cancerous ascites belong to the respective group in the order mentioned.

2. The case in which tumor cells and tumorous signet-ring cells can be verified is designated as the direct symptom, while those specific characteristics in tumorous ascites
\end{abstract}


showing cells other than tumor cells, such as phagocytes and seruous cells, are to be designated as the indirect symptoms.

3. Tumor cells themselves will assume various shapes according to the lind of tumor and by their morphological characteristics even gastric cancer can be distinguished as glandular, simple, solid, or colloidal cancers. And likewise ccelothelioma cells present still more specific morphological traits, revealing a transformation picture to serous cells. In liver cancer cells there are specific granules, and sarsoma cells of reticulosarcoma and others present characteristics different from cancer cells.

4. Viewing the indirect symptom, phagocytes look ugly and serous cells show a strong degenerative tendency or a strong atypical appearance, and neutrophils also degenerate rapidly. From these findings cancer can be readily distinguisshed from other diseases such as liver cirrhosis, tuberculous peritonitis, etc.

5. Cytological observations of ascises as carried throughout parts 3 and 4 clearly prove to be a useful method for the clinical differential diagnosis of ascites in various diseases. 


\section{嘉 村論文附図}

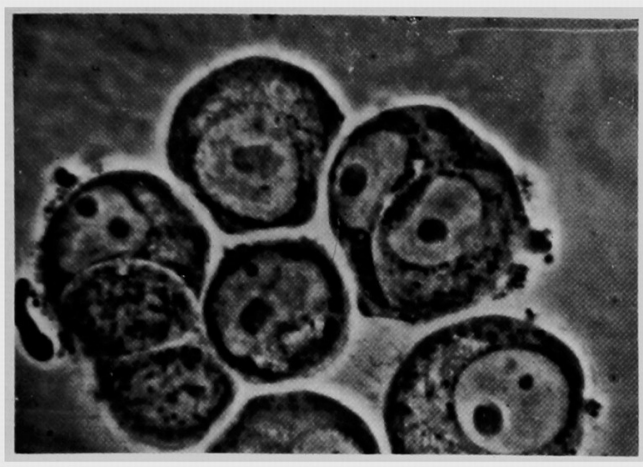

写真 1. 刑癌腹水癌細胞 DLL. $\times 1000$

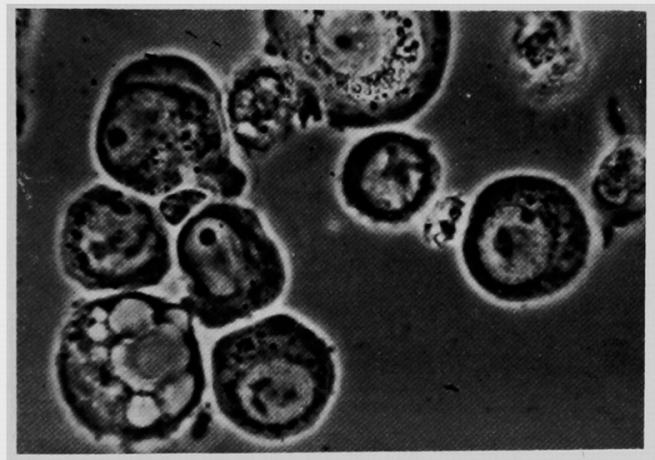

写真 3. 胃癌腹水癌細胞 DLL $\times 1000$

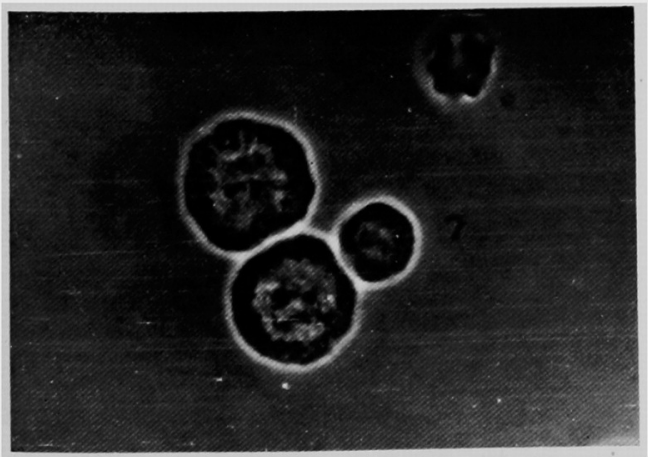

写真 5. 単純癌細胞 DLL. $\times 1000$

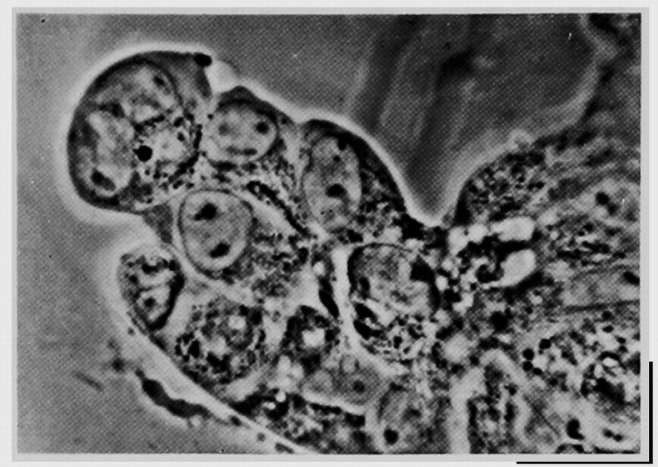

军真 2. 胃癌腹水癌細胞 DLL. $\times 1000$

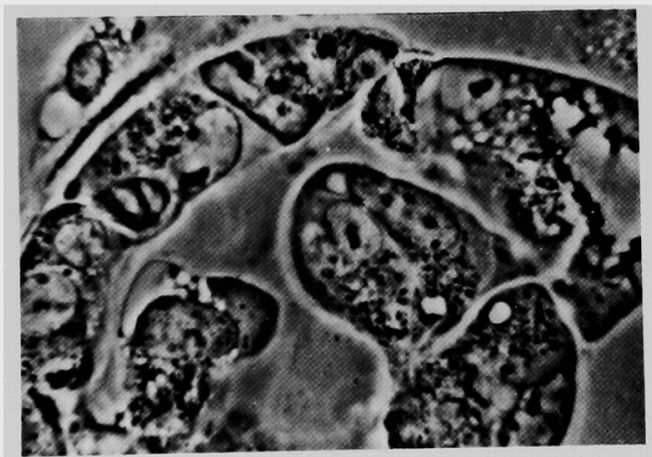

写真 4. 腺癌細胞 DLL. $\times 1000$

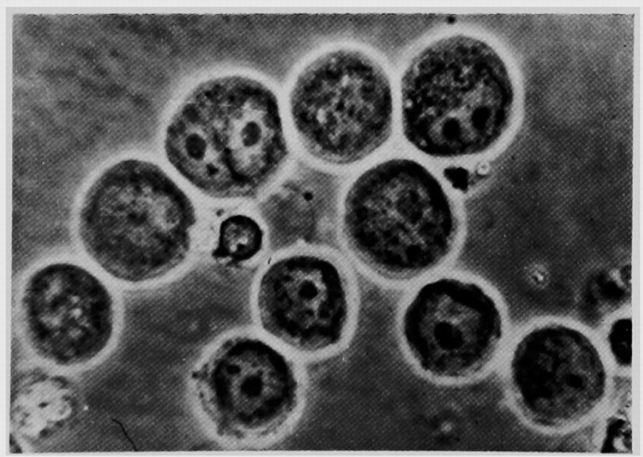

写真 6. 硬性癌細胞 DLL. $\times 1000$ 


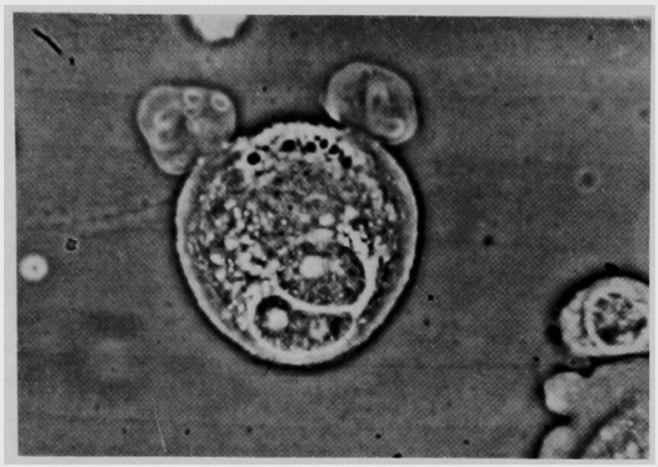

写真 7. 体腔上皮腫細胞 BM. $\times 1000$

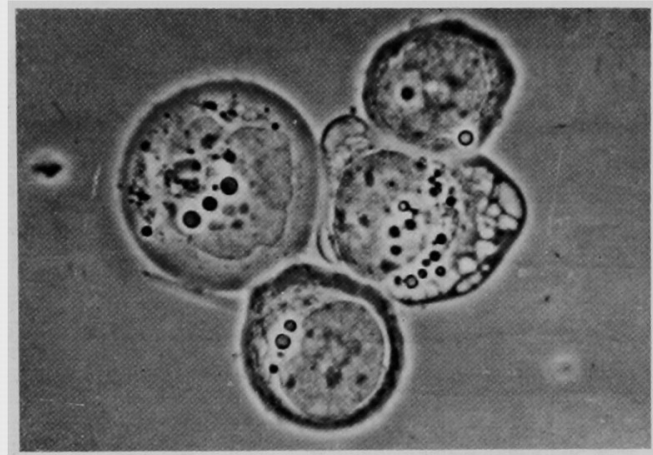

写真 9. 細網肉腫細胞 DLL. $\times 1000$

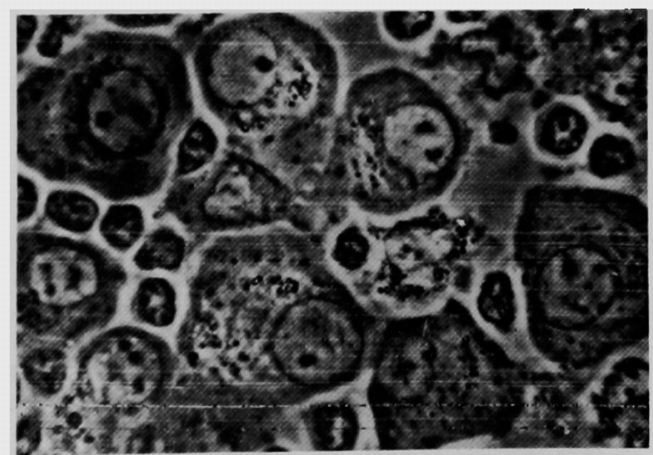

写真11 癌性腹水族膜細胞（異型漿膜細胞） DLL. $\times 1000$

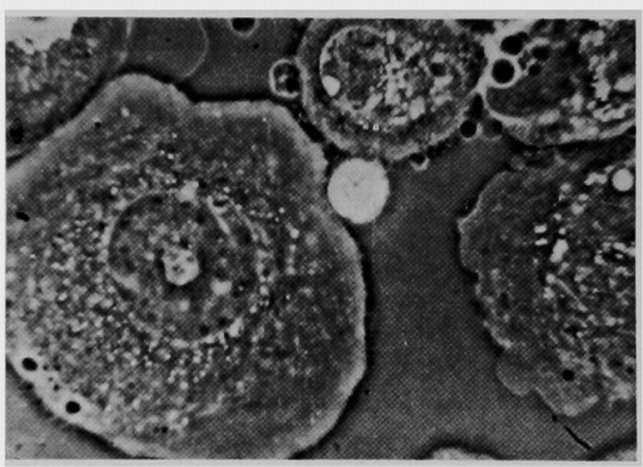

写真 8. 体腔上皮腫細胞 BM. $\times 1000$

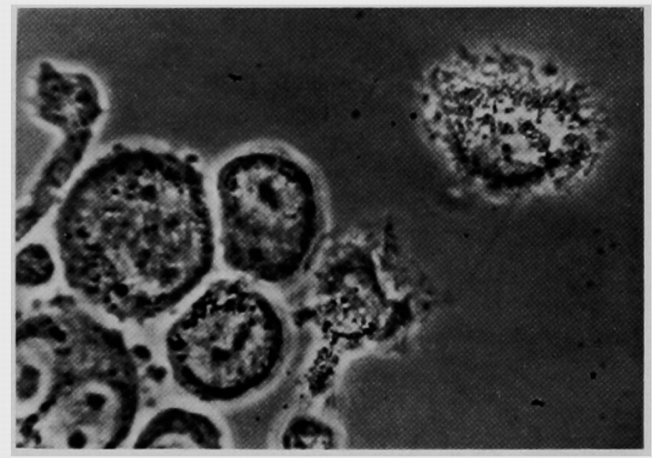

写真 10. 癌性腹水，右 2 個食細胞 DLL. $\times 1000$

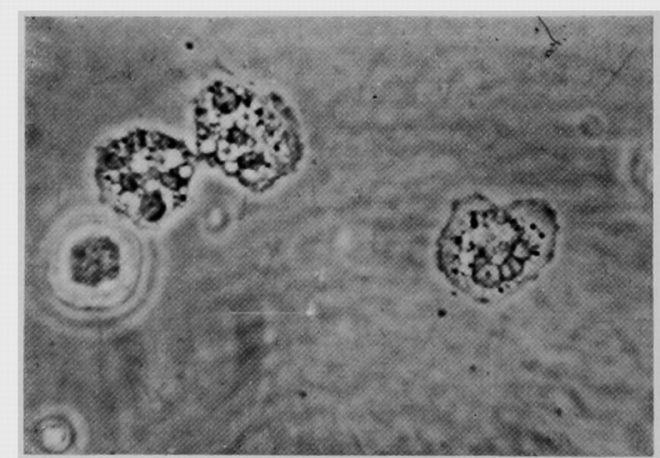

写真12. 癌性腹水, 好中球 DLL. $\times 1000$ 